\title{
Leadership Development in Ghana: A New Look at an Old Concept
}

Emmanuel Osafo and Robert M. Yawson

\section{INTRODUCTION}

We all might have been asked the question "are leaders born or made?" This question might have led to a healthy debate in a conversation or some academic discourse. However, to most traditional leadership systems where leadership is by kin selection, the forthright belief is leaders are born. Thus, an individual should share blood relations with a particular lineage to increase their chances of becoming a leader. It should, however, be noted that even in the most extreme cases where people are born to inherit from their predecessors, some form of development is required for them to be effective in their leadership roles. Leadership development is, therefore, germane to every kind of leadership.

Leadership development in Ghana is a complex and important practice and can be discussed under many topical areas. However, in this chapter, we focus on popular models such as traditional leadership development and leadership development through education, among others, to

\section{E. Osafo $(\bowtie)$}

University of Minnesota, Minneapolis, MN, USA

R.M. Yawson

Quinnipiac University, Hamden, CT, USA

(C) The Author(s) 2017 
guide our overall discussion of leadership development in Ghana. There is a dearth of literature on leadership development in Ghana. The existing empirical work on leadership development in Africa is premised on a desire to provide Western expatriates with a better understanding of how to do business in Africa. There is the need for empirical work that will provide a better understanding of traditional leadership development in various African countries and communities to help assist employees, organizations, and communities appreciate, develop, and enhance their leadership development approaches (Bolden \& Kirk, 2009). We proceed by providing a brief description of Ghana and some of the traditional systems that influence leadership development. The proceeding sections will discuss various models of leadership and leadership development, including traditional and political leadership, leadership development through education and religious institutions, and contemporary views on leadership development in the country. The chapter will end with a comparison of the strengths, challenges, and commonalities among the models, and a conclusion.

\section{A Brief Description of Ghana}

Ghana is a sub-Saharan country situated along the Atlantic coast of West Africa. The total land area is approximately 240,000 square kilometers. The distance from north to south measures about 672 kilometers, and 560 kilometers from east to west. Ghana is bordered to the east by Togo, west by Cote D'Ivoire, to the north by Burkina Faso, and to the south by the Gulf of Guinea. Ghana is believed to be the country that is nearest to the center of the earth, with the Greenwich Meridian that passes through Tema, a coastal town in Ghana, meeting the equator off the shores of Ghana. Based on the 2013 census data, Ghana's population is estimated to be around 25.9 million, divided across ten regions that form the administrative divisions of the republic. Ghana has an agrarian economy with estimated 60 percent of the population engaged in subsistence agriculture. The country is a parliamentary democracy with a 275 -seat unicameral legislature governed under a constitution with a president who serves as both head of state and head of government (Columbia University, 2012). Both the president and the legislature are elected by universal adult suffrage for four-year terms; the president's tenure is limited to two terms. Administratively, there are 6 metropolitan and 55 municipal councils that are subdivided into 212 districts that form the district assemblies. 
Ghana was among the first sub-Saharan African countries to allow Europeans to settle on their soil in the fifteenth century, one of the earliest to be colonized in 1874, and one of the first to gain independence from the Europeans in 1957 (Salm \& Falola, 2002). It is estimated that 69 percent of the population is Christian (Pentecostal and other Protestant churches, and Roman Catholic) and 16 percent is Muslim, with the remainder following traditional religions (Nelson, Ingols, Christian-Murtie, \& Myers, 2013).

Ghana is a multi-ethnolinguistic country with English as the official language. It is a country that can be described as a conglomeration of tribes each of which has unique characteristics that define their traditional leadership development and general livelihood. However, there are general modalities of leadership development that cut across all tribes in the country. For the purpose of this chapter, emphases will be on the general modalities for traditional leadership development.

\section{LeAdership DeVelopment in Ghana}

The conceptualization and description of leadership development have not been consistent across countries. For example, Africa is by no means a monolithic entity with a vast cultural diversity, although "certain indigenous trends of thought, cultural influence, and value orientation are commonly shared by the majority of people in Africa" (Edoho, 2001, p. 79). However, there is the tendency of describing leadership development in the context of Africa monolithically from the Western perspective (Amenumey \& Yawson, 2013). Particularly, the whole concept and practice of leadership in the Western world are to some extent different from most emerging economies (Amenumey \& Yawson, 2013). In this chapter, we attempt to describe how leadership development is conceptualized and practiced in Ghana; however, we do not suggest that the case of Ghana is a microcosm of the entire situation in Africa or that of other emerging markets.

\section{Traditional Leadership Development in Ghana}

Traditional leadership is an important part of leadership in Ghana's sociopolitical system. During the precolonial era-the period before Ghana was colonized by the British-traditional leaders were the center of development and continued to play an important role in Ghana's developmental 
efforts. "Traditional leaders/chiefs can claim special legitimacy in the eyes of their people because these institutions can be seen to embody their people's history, culture, laws and values, religion, and even remnants of pre-colonial sovereignty" (Ray, 2003, p. 5).

Leadership development in Ghana is grounded in the country's traditional sociopolitical systems such that it will be deficient to discuss this topical area without referring to the modalities used in developing Ghana's traditional leaders. Leadership development in the traditional system is as complex as it is interesting. Ghana's traditional sociocultural system is heterogeneous such that different tribes observe certain unique values and customs that distinguish them from other tribes. However, in a general sense, each member of the society has a responsibility to respect the traditional authority that ensures peaceful coexistence of residents in their jurisdiction, irrespective of their tribal affiliations. Traditional leaders in Ghana are vested with the authority to mobilize their subjects for development, to inspire them to behave morally, and to impact public discourse in a positive manner (Ray, 2003). Incontrovertibly, traditional leadership cannot be ignored in discussing leadership development in Ghana.

To understand traditional leadership development in Ghana requires a good understanding of the social stratification and inheritance systems. The social system of Ghana can be described as a network of individuals bonded together by blood relations and geographical location. Thus, a collection of individuals forms a family, a collection of families forms a clan, a collection of clans forms a town, and a collection of towns form a tribe. At every level, there are procedures for leadership selection and development that all members must understand and uphold. The father assumes leadership position of every family by default; the lineage head is the head of the clan; the chief is the head of the town, and the paramount chief is the head of the tribe. The queen mother is the female leader who has the joint responsibility with the chief to promote the development and well-being of the community and the people in their jurisdiction. The queen mother is also the principal custodian of the oral traditions and the one who leads the determination of the rightful successors to leadership roles (Gibson, 1995).

In Ghana, the traditional system of leadership development uses an inclusive model that requires every family's representation at the palace that serves as the residence of the chief where all dignitaries are received. Also, all major political and economic decisions are made at the palace. To this effect, every family is assigned a specific role that they play in the 
developmental effort of their community. There are many subdivisions in the leadership circle of Ghana's traditional system that can be equated to the modern system of leadership. For instance, as one family assumes the responsibility of finance, another assumes the responsibility of security. Every family is required to develop their kinsmen for future leadership roles in the palace because only kinsmen from a particular family have the birthright to succeed a particular sub-chief when they die.

Traditional leadership development in Ghana involves a unique set of training that ensures the individual leaders understand their role and also conduct themselves credibly. This model of leadership development focusses on teaching individuals the customary rights, public speaking, dancing to the tune of traditional drums, dispute adjudication, ethical conduct, and other ancestral heritage because of strong belief that these and "other local matters, are best expressed by traditional leaders" (Ray, 2003 , p. 5). Competency-based modeling themes underlie these training experiences. For instance, being a traditional leader in Ghana requires knowledge of an individual's customary rites, ability to adjudicate disputes effectively, and skills in particular assignments to the ancestors at the chief's palace. This model is in convention with the knowledge, skills, abilities, and other characteristics (KSAO) model that is emphasized by industrial and organizational psychologists and scholars from other business related fields.

Competence and character are two important elements of traditional leadership development in Ghana. Alabi and Alabi (2014, p. 124) emphasized that traditional leadership competencies in Ghana include: administrative competences (planning, and organizing resources); people competences (respect, patience, listening, conflict management, negotiations skills, facilitation of peace and harmony, and being a change agent and role model); visionary competences (strategic thinking, networking, ability to establish the requisite social capital); and personal competences (honesty, trustworthiness, credibility, self-awareness, confidence, and selfrespect). These are some of the leadership attributes emphasized by traditional leadership development models in Ghana.

There are no written models that guide traditional leadership development in Ghana. However, there are various informal information dissemination mechanisms that are used to ensure information flow from one generation to another. These include assigning unique meanings to particular artifacts that symbolize significant events that occurred in the past. For example, the picture or carving of a dog with flaming fire in 
the mouth is one clan's symbol. Those who aspire to be leaders of that clan need to know the history of such artifacts and their implications for that particular family. This is critical to traditional leadership development in Ghana because belief systems and symbolism are very important to practicing leadership duties. Traditional leadership development modalities are rooted in the customs and traditions of a particular tribe and are transferred from one generation to another through interpretive discussions. In the case of unresolved ambiguities, the elderly who are deemed knowledgeable in all aspects of the customs and traditions are consulted for clarification. Three primary modalities used for traditional leadership development in Ghana are storytelling, coaching, and mentoring. Each of these modalities will be discussed next.

Storytelling. Storytelling is one of the bedrocks of traditional leadership development in Ghana. Many researchers have emphasized the significance of storytelling in leadership development (Bennis, 1996). Alexander Mackenzie (2014) indicated in his popular article, "Storytelling Is the Heart of Leadership" that, "a good leader is a good story teller" (Mackenzie, 2014, p. 1). For example, Kofi Annan, a Ghanaian diplomat and former United Nations Secretary General, was described by one of his advisers to a journalist in the following way: "he runs the U.N. like an old fashioned African Village, with long discussions among the elders, periods of reflection and eventually a decision" (Mintzberg, 2010, p. 6). Perhaps unknowingly to this adviser, he was describing the storytelling approach to traditional leadership development. Ready (2002) indicated that storytelling is an effective means of communicating important messages related to culture and that "great stories create a rich visual imagery in our minds" (p. 64). Through storytelling, leaders self-disclose themselves and engage and inspire others (Harris \& Barnes, 2006). The storytelling approach to traditional leadership development in Ghana helps to remind leaders of their responsibilities and commitment to their subjects. Through storytelling, leaders continuously educate the youth and visitors about the reasons behind certain actions and the need to preserve their customs and traditions.

Coaching. Another popular approach to traditional leadership development in Ghana is coaching. Coaching is the one-on-one process through which leaders confront their competencies to lead and develop an awareness of the way to master this capability (O'Flaherty \& Everson, 2005 , p. 2). Coaching is critical in traditional leadership development in Ghana because there is no documented information on the requirements 
of a leader. However, just as coaching from a Western perspective is a formal process, with assessment and deliverables attached to it, the traditional approach to coaching in Ghana has some form of formal component of assessment and deliverables as well. Hence, young people who aspire to hold leadership roles need to have one-on-one interactions with the elderly to be able to understand the customs and artifacts that define the traditions of society. Coaching served as an important tool for preserving and passing on time-tested skills, customs, and knowledge from generation to generation, and the mastery of these attributes are assessed in different ways, including initiation ceremonies (Adeyemi \& Adeyinka, 2002). In line with the views of Mccormick and Burch (2008), coaching is used to shape the personality of potential leaders in the Ghanaian traditional system and also to identify deficiencies in essential traits for effective leadership. Skills such as communication, articulation of vision, and interpersonal relationships are developed through coaching. When the family identifies individuals as potential leaders, these individuals are assigned elderly persons who work closely with them, teaching them about the traditions and customs and encouraging them to practice such in public occasionally. Mistakes are corrected as the development process goes on until the individual is confident to act with little guidance. Coaching continues throughout the leadership development process.

Mentorship. Mentoring is another approach used in traditional leadership development in Ghana. Because traditional leadership in Ghana is usually kin-based, succession planning is critical. Mentoring is a leadership development process in which "an experienced colleague engages in the professional development of a less experienced colleague" (Dziczkowski, 2013 , p. 355). As indicated by Dziczkowski (2013), mentoring helps to reduce stress and anxiety related to taking on new responsibilities and lead to greater self-awareness. Identifying credible persons and preparing them to take leadership roles whenever the need arises is a difficult task in the traditional societies of Ghana. Selection is based on the individuals' personal conduct among his peers. Young men who are identified as potential leaders are recognized as conducting themselves credibly and with no visible disabilities and have not been convicted of any crime. It should be noted that selection is focused mainly on the males, except for a few instances where females are targeted for the queen mother position. Some of these selection criteria have come under heavy criticism as dated tradition which is discriminatory regarding gender and disability. Potential leaders are informally mentored by an elderly person in a leader- 
ship role who guides them through life in a manner that transcends ordinarily growing up in a community. Mentors are usually respected people in society who have made a significant contribution to their community. A mentor should be knowledgeable in traditional and customary matters and identified as a competent "teacher" who is patient and can disseminate information accurately. Traditional leadership mentees are assigned leadership roles among their peers and are monitored closely by the elderly person whose responsibility it is to shape the mentee's character in a manner that helps to keep a balance between traditionally sanctioned and personal conduct.

Mentees are usually observed by their peers as having special characteristics and enjoying exceptional privileges in the community. In a typical traditional system in Ghana, mentees build their character and assume some level of authority among their peers during the extended period of mentorship when they understudy a more experienced leader. They are introduced to the key functions of leadership and are provided the opportunity to practice such and participate in decision-making processes. Processes used for traditional leadership development are still relevant in Ghana's current developmental efforts. Even with absolute colonization that impacted the lives of the people of Ghana, major traces of traditional leadership development modalities have translated into all aspects of leadership development in the country.

\section{Political Leadership Development in Ghana}

There is a thin line to cross when differentiating between traditional leadership and political leadership in Ghana. Prior to the Europeans arriving in Ghana, the traditional leaders controlled all the resources of the state and acted as the trustee of all state lands. Since gaining independence in 1957, there has been a complete divide between traditional leadership and political leadership, even though the structure and functions of the two merge at a point. Generally, political leadership refers to the central government comprising of the executive, judiciary, and legislative branches, or a dictator and his appointees who assume power through the forceful takeover of government. The main criterion for selecting traditional leaders in Ghana is blood relations, but political leaders in Ghana have been selected through the polls, coup d'état, or through appointment by a president or head of state. For the purpose of this discussion, political appointees to 
other state institutions such as the central bank and the police are considered under political leadership.

Political leadership development in Ghana is erratic. Thus, there is no clear-cut model for developing political leaders. The history of political leadership development dates back to the precolonial era; however, in this chapter we focused on the period after Second World War and the postcolonial era in Ghana. We begin the discussion of political leadership development in Ghana with a brief discussion of the Big Six; the six Ghanaian leaders who spearheaded Ghana's independence.

The Big Six. Redirection in Ghana's political leadership development began with the fight for independence. During this period, prominent Ghanaians both at home and abroad came together to help liberate the nation from British rule. The struggle for independence led to the creation of a group of leaders who frequently met with the colonial government and negotiated to design a path to independence. In early March 1948, the leadership of the United Gold Coast Convention, the leading political party in the British colony of the Gold Coast, was arrested in connection with some disturbances in Accra, the capital of the then Gold Coast, as Ghana was previously named. Following the disturbances, six leaders of the fight for independence were arrested and detained by the colonial government. The leaders who were arrested were Kwame Nkrumah, Obetsebi-Lamptey, Ako Adjei, Edward Akuffo-Addo, J. B. Danquah, and William Ofori Atta. These leaders were tagged the Big Six by the people of Ghana.

The emergence of the Big Six and subsequently gaining independence provided the impetus for political leadership development in Ghana. It should be noted that Kwame Nkrumah formed his Convention Peoples' Party (CPP) in 1949 and eventually fell apart with the Big Six. Interestingly two of the Big Six, Kwame Nkrumah and Edward Akuffo addo, respectively, became the first and second presidents of Ghana. To date, all political party activities revolve around the CPP and United Party, which was born out of the UGCC.

Similar to many newly independent countries, Ghana identified education as the key to social and economic development (Akyeampong, 2010). There is controversy on the actual date formal education started in Ghana. For example, information from Great Pola Foundation indicated that European merchants such as the Danes, Dutch, and English started educating their offspring with native Ghanaian women in the castles and forts to take up positions as administrative secretaries and soldiers. 
Other sources claim the first school was established by the Portuguese in 1529 at the Elmina Castle. Another source indicates that formal education in Ghana started in 1752 (Jones, Jones, \& Ndaruhutse, 2014), but focus on character training that is essential for leadership development became apparent after a petition was made to the then colonial Governor Guggisberg in 1920 (Agbodeka, 1977). Since this period, Ghana's educational system directed more attention to character training and leadership development.

\section{Leadership Development Through Education}

The post-independence era saw schools in Ghana gingered up for leadership development. The boarding school system, which was the predominant system for secondary- and tertiary-level education in Ghana, provided grounds for leadership development. As indicated by Jones et al. (2014), the boarding system brought together students from diverse geographical locations who had completely different ethnic and socioeconomic backgrounds. Living together in the dormitories and halls at the universities inspired sharing of values and establishing a common ground for collaboration and respect for one another. According to Jones et al. (2014), this created a more horizontal leadership development system built on respect and equality in Ghana. The nature of the boarding school system in Ghana encouraged brilliant students to travel across the country to attend school in any district of their choice. The most selective prestigious schools, mainly in the southern part of Ghana, were targeted by most brilliant students. The boarding school system presented luxuriant grounds for leadership development. Because most young people spent their teenage years in boarding schools, their character formation and skill development potentials were formulated in these environments.

Between 1966 and 1992, Ghana's political landscape suffered a period of precarious atmosphere that scared both ordinary citizens and business owners. Unpredictable coup d'états that resulted in the abuse of civil rights and liberties of the people and unwarranted business takeovers by the military were so predominant that democratic political activities were distasteful to potential leaders. However, in the boarding schools, internal political campaigns were launched and elections held to select leaders in a democratic manner to manage the affairs of the secondary and tertiary institutions. Other students who could not get the opportunity to serve as Student Representative Council (SRC) executives were encouraged 
to participate in leadership roles in their classrooms and dormitories and other social groups on campus. Because of the extended stay in the boarding schools, usually between five and ten years from secondary school to the tertiary-level institution, most people who had leadership potential had the opportunity to shape their character and sharpen their leadership skills while in school.

Interestingly, most of the notable leaders in Ghana were products of the boarding school system and had served in one leadership capacity or another while in their schools. Many prestigious selective schools such as Achimota and Mfantsipim Secondary Schools enjoyed the benefit of a diversified student population that enriched their leadership development efforts. Until today, most leaders in Ghana have some affiliation with one or another prestigious selective boarding school. For instance, renowned leaders like K. A. Busia, a former prime minister of Ghana, and Kofi Anan, the immediate past United Nations Secretary General, were products of Mfantsipim Secondary School. Also, Achimota School produced notable leaders like Kwame Nkrumah, Jerry John Rawlings, and Evans Attah Mills, all of whom were once elected presidents of the Republic of Ghana.

At the tertiary education level, elections in student organizations such as the Students' Representative Council (SRC) and the National Union of Ghana Students (NUGS) are contested with the gravity attached to any national elections. At this level, students who aspire to be political leaders align themselves with particular political parties and work tirelessly to shape their public speaking, decision-making, sobriety, and selfpresentation skills among other things. Student leaders develop leadership qualities such as a sense of integrity, commitment to duty, negotiation skills, interpersonal relationship, decisiveness, and confidence through their leadership roles and constant contact with national leaders.

Models used for leadership development in the boarding schools in Ghana are no different from those used for traditional leadership development. Coaching and mentorship were predominantly used for leadership development at the boarding schools. In a succession planning style, student leaders would identify and groom junior students and inspire them to take over when they graduate. In a kin-selection-like manner, senior students would identify with junior students who share something common with them and mentor them as their potential successors. This phenomenon developed into the mainstream national politics and civil service where the selection of leaders is to a large extent by cronyism with little recognition to competence until today. 
Also prominent was the establishment of the Ghana Institute of Management and Public Administration (GIMPA) in 1961 to train public servants to acquire administrative and professional competence to run the affairs of governmental institutions. GIMPA is now a full-fledged university offering courses in leadership to help improve leadership effectiveness in Ghana. The Institute of Professional Studies (University of Professional Studies) was also established in 1965 to train accountants and management professionals to lead the financial administration of the industrial and organizational sectors of Ghana. Other institutions such as the military, customs, immigration service, and the police established special institutions to lead in various capacities. Leadership development through education is still important in Ghana.

\section{Religion and Leadership Development in Ghana}

Religion is another aspect of Ghanaian life that has contributed to leadership development. Before the arrival of the Europeans, traditional priests served as the spiritual leaders who had the prowess to interpret issues of spiritual dimensions. The traditional priests were consulted on many issues such as the prevalence of some strange diseases or unexplained deaths. Today, traditional priests continue to assume some level of relevance in many rural communities in Ghana. Every chief worked closely with a traditional priest who served as their spiritual leader. Training and development of traditional priests were mainly through coaching and mentoring.

In the early nineteenth century, Christianity was introduced to Ghana (then the Gold Coast) by "missionaries from the Basel, Bremen, Methodist, and the Anglican missions" (Nilsson, 2003, p. 11). The introduction of Christianity into the Ghanaian society resulted in a shift in leadership development. As part of their mission goals, churches established schools in Ghana to train children in both moral issues and other mainstream subjects such as English and math. The establishment of mission schools required new dynamics in leadership to spearhead the new system. To this effect, teachers were trained to not only lead the schools but also to lead the church and other community activities. The introduction of teacher training education led to a shift in the male-dominated traditional system to include females who served as teachers and opinion leaders in their communities. Many people who trained as teachers moved higher on the academic ladder and eventually became national leaders. Typical examples 
are Kwame Nkrumah, who eventually became the first president of Ghana and K.A. Busia, who also became the first prime minister.

Besides directly training people to become leaders, the Christian religion also helped to shape the character of school children. Teachers were trained to show exemplary character in all their endeavors. This attitude helped to form a society of leaders who were measured not only by performance on tasks but also by their personal conduct and interpersonal relationships. Up to date, teachers serve as prominent leaders in their communities. The foundation laid by religious groups in the early 1900s has inspired teachers to lead many initiatives in Ghana. For example, teachers were identified as strategic leaders in Information and Communication Technologies (ICTs) training in Ghana. With the mass implementation of the Junior Secondary School (JSS) system with a focus on vocational training in the late 1980s teachers were targeted to receive training in many vocational skill sets, including ICT, to lead the new system to success. Teachers' contributions to the development of communities are visible in every corner of Ghana. Until today, teachers serve as opinion leaders and spearhead most development efforts especially in rural Ghana.

Since the early 1980s, the charismatic group of churches (a Christian movement that emphasizes the works of the Holy Spirit, spiritual gifts, and miracles) began a leadership crusade aimed at liberating people from socalled "ancestral curses" and leading them into prosperity. Many of these churches organized crusades to help people become leaders and prosperous members of society. Eventually, some religious institutions extended their activities to establish formal tertiary institutions and other pastoral training schools to help train leaders of distinct character. Pastors and other church leaders continue to contribute in diverse ways to leadership development in Ghana. For example, the International Central Gospel Church (ICGC) initiated the pastoral training college in 1988 which eventually metamorphosed into a full-fledged university with a mission goal of nurturing a vibrant academic community conducive for the study, creation, and dissemination of knowledge through research, training, and service in 1997. The Islamic University was also established in 1995 to train the youth to be qualified professionals.

Other religious institutions such as the Christian Council and the Ghana Moslem Mission continue to play key leadership roles in fostering unity and ensuring peaceful coexistence with other religious bodies for national development. The role of religion in leadership development in Ghana is so important that the government consults and collaborates with religious 
leaders to solve many pertinent national issues. Pastors and other religious leaders serve as marriage counselors and community leaders in Ghana. Even though Christianity dominates religion in Ghana, the traditional priests continue to serve as spiritual leaders in most rural communities.

\section{Contemporary Views on Leadership Development in Ghana}

In spite of the efforts put into leadership development since independence, many scholars have blamed the underdevelopment in Ghana and Africa as a whole on poor leadership. For example, Ake (1993) stated that "poor leadership and structural constraints have turned the high expectations of the independence movement into painful disappointment" (p. 240). Some writers have blamed the underdevelopment of Africa on the corruption of people in leadership ranks. In an attempt to curb this disturbing phenomenon, institutions have been set up to develop leaders of integrity to spearhead the developmental efforts of Ghana. In 2009, the Center for Creative Leadership (CCL) organized a training session in Ghana to help develop leaders. The Graduate School of Governance and Leadership was incorporated in Ghana in the year 2004 to provide short-term training and development programs for corporate and business executives. Most universities have introduced leadership development programs at various levels through the social science departments.

Essential to contemporary leadership development efforts is the influx of private universities in Ghana. With a perceived gap in skills development, many of these private universities were established to help produce skillful individuals to lead the way in ensuring effectiveness in the Ghanaian system. However, with a deficit in job placement, many of these perceived leaders are redundant. Ironically, the leadership development models used by the traditional leaders and the boarding school systems (including mentorship, coaching, and storytelling) continue to dominate leadership development activities in Ghana.

We agree with Mintzberg (2010) that "the more we try to develop leaders, the more we seem to get hubris"(p. 9) because in an attempt to develop leaders, products of our universities who are trained to lead sometimes exhibit behaviors that depict self-indulgence with little focus on their assigned role. Mintzberg (2010) proposed fostering leadership rather than developing leadership as the way forward for the developing world, including Ghana. According to Mintzberg (2010), fostering leadership is contextual and helps to identify people who are in the situ- 
ation to lead. The question is, should Ghana return to the typical traditional leadership development approach? Answering this question requires a closer look at some contemporary indigenous leadership organizations part of whose goal is leadership development. Many scholars have argued that efforts to engineer authentic leadership development will continue to be unsuccessful until traditional leadership models are established and institutionalized (Nkomo, 2006). We are also of the view that further research is required on leadership in Ghana that steps outside dominant methodological and empirical paradigms. Furthermore, we propose that such work holds great potential for generating insights not just relevant to leadership development in Ghana but leadership studies in general. There is, however, the need for hybridity of existing leadership development models shaped through complex and multilayered social, cultural, and historical contexts of traditional leadership principles as outlined in this chapter. Hybridity in this regard is not a proposition for mimicking Western practices or attempting a return to idealized notions of "traditional" leadership but instead offers a means for adaptation and change (Bolden \& Kirk, 2009).

Many organizations from around the world are currently in Ghana promising to train leaders in diverse capacities. With the discovery of oil in commercial quantities in Ghana in 2008, organizations such as MDT International and LEORON Professional Development Institute have extended their operations to Ghana with the goal of training professionals to lead the oil and gas industry and to manage projects. Ironically, all these foreign organizations do not consider the indigenous systems in their leadership development goals. As indicated by Mintzberg (2010), thinking that what has worked in New York can work in Accra is a misconception. Thus, contextualization is important in the design and implementation of leadership development programs.

Indigenous leadership development institutions. Organizations such as Leadership Ghana were established with the goal of training indigenous Ghanaians to understand the essence of culture in national development. The Institute of Economic Affairs (IEA) aims at promoting good governance, democracy, and free and fair market economy. The Center for Democratic Development (CDD) aims at promoting democracy, good governance, and economic openness in Ghana and Africa. The Kofi Annan International Peace Keeping Training Center aims at providing the capacity for African peace and security through training, education, and research. Imani Center for Policy and Education aims at promot- 
ing economic prosperity through continuous education of individuals on the value of free markets and human initiative through entrepreneurship. Leadership development themes underlie the missions of all these institutions. Most of these indigenous leadership development institutions organize short-term seminars and conferences with the goal of developing leaders. However, it is difficult to identify specific ways by which these indigenous institutions incorporate traditional models into their developmental efforts. Therefore, effectiveness of these seminars and conferences on the individual participants' leadership skills needs further scrutiny.

\section{Strengths, Challenges, and Commonalities of the Leadership Development Models}

There are commonalities among the various leadership development approaches discussed. As shown in Table 12.1, each of these models has its strengths and challenges, but there are also some common themes that transcend the models. An example is the power distance often created as a result of the various approaches. In spite of its shortcomings, traditional leadership development is an effective way of preparing young people for their future, just like all the other models (Adeyemi \& Adeyinka, 2002). The hybridization of the strengths of the various models will serve as a unique and effective leadership development approach and also help mitigate the challenges inherent in the individual models. Hybridity of the leadership development models will be an effective means of improving the economic, social, and cultural structures and stability of the Ghanaian society and prepare young people to come to terms with the physical, social, and spiritual world of work (Adeyemi \& Adeyinka, 2002).

Considering the manner in which the chieftaincy institutions in Ghana have survived over the years and continue to influence decision-making, it is important for Ghanaians to revive and focus on traditional models in leadership developmental efforts for sustainability and effectiveness. There are no clear-cut models for leadership development. However, some elements of the traditional models are commonly present in Ghanaian organizations. Many organizations in the past might have survived because they inculcated the leadership development models used in the traditional system. Beyond the boarding schools and the religious training received by employees, organizations adopted coaching and mentoring of potential leaders as their succession planning strategy. Owners of most indigenous organizations, which formed the majority of employers in Ghana, 
Table 12.1 Comparison of the different leadership development patterns in Ghana

\begin{tabular}{|c|c|c|c|}
\hline LD Model & Strengths & Challenges & $\begin{array}{l}\text { Commonalities } \\
\text { among models }\end{array}$ \\
\hline Traditional & $\begin{array}{l}\text { 1. Deeply rooted } \\
\text { in indigenous } \\
\text { forms, making } \\
\text { it original and } \\
\text { accepted and } \\
\text { respected by } \\
\text { the people. } \\
\text { 2. Preserves } \\
\text { cultural values } \\
\text { and promotes } \\
\text { communality. } \\
\text { 3. Leaders acquire } \\
\text { a communal } \\
\text { rather than an } \\
\text { individualistic } \\
\text { outlook. }\end{array}$ & $\begin{array}{l}\text { 1. No written-down } \\
\text { steps to follow, } \\
\text { resulting in } \\
\text { information lost } \\
\text { with time. } \\
\text { 2. Focuses more on } \\
\text { lineage than } \\
\text { competence and } \\
\text { resourcefulness. } \\
\text { 3. Focuses almost } \\
\text { exclusively on the } \\
\text { clan or tribe and } \\
\text { hardly prepares its } \\
\text { recipients for } \\
\text { outside contact. }\end{array}$ & $\begin{array}{l}\text { High power distance } \\
\text { between "Royals" who } \\
\text { are perceived as the } \\
\text { privileged in society and } \\
\text { subjects who are } \\
\text { required to submit to } \\
\text { the Royals. }\end{array}$ \\
\hline Education based & $\begin{array}{l}\text { Promotes } \\
\text { relationship } \\
\text { building and } \\
\text { networking. }\end{array}$ & $\begin{array}{l}\text { Cultural } \\
\text { contamination: } \\
\text { Students learn from } \\
\text { their mates' culture, } \\
\text { resulting in the } \\
\text { weakening of tribal } \\
\text { customs and } \\
\text { traditions. }\end{array}$ & $\begin{array}{l}\text { High power distance } \\
\text { resulting from elitist } \\
\text { thinking. }\end{array}$ \\
\hline Religion based & $\begin{array}{l}\text { Promotes } \\
\text { discipline and } \\
\text { benevolence. }\end{array}$ & $\begin{array}{l}\text { Tendency for } \\
\text { doctrinal purity } \\
\text { resulting in religious } \\
\text { fundamentalism and } \\
\text { conflicts. }\end{array}$ & $\begin{array}{l}\text { Indoctrination results in } \\
\text { submissiveness of the } \\
\text { member to the leader, } \\
\text { creating a condition of } \\
\text { high power distance. }\end{array}$ \\
\hline $\begin{array}{l}\text { Contemporary } \\
\text { views }\end{array}$ & $\begin{array}{l}\text { Uses modern } \\
\text { scientific methods. }\end{array}$ & $\begin{array}{l}\text { Rooted in Western } \\
\text { colonialist thinking. } \\
\text { Hence, removed } \\
\text { from indigenous } \\
\text { forms. }\end{array}$ & $\begin{array}{l}\text { Those with scientific } \\
\text { knowledge are } \\
\text { perceived as experts } \\
\text { whose views are often } \\
\text { taken as sacrosanct, } \\
\text { arrogating them } \\
\text { authority to control the } \\
\text { agenda for leadership } \\
\text { development and } \\
\text { creating a condition of } \\
\text { high power distance. }\end{array}$ \\
\hline
\end{tabular}


groomed their relatives to take over leadership roles whenever a vacancy was available. Even with the foreign-owned organizations, leadership positions were filled with people who had risen through the ranks.

\section{Conclusion}

Leadership development in Ghana has seen several transformations regarding institutional change and systemic adjustments to match the needs of the times. However, one thing that has attracted relatively constant attention is the models used in traditional leadership development. Furthermore, the contribution of education and religious organizations to leadership development in Ghana cannot be understated. However, inculcating elements of coaching and mentoring in the school curriculum will help improve the leadership skills of products of Ghana's secondary and tertiary institutions. Also, religious bodies are encouraged to infuse some aspects of the leadership development culture of the traditional system into their leadership development programs for sustainability.

\section{REFERENCES}

Adeyemi, M. B., \& Adeyinka, A. A. (2002). Some key issues in African traditional education. McGill Journal of Education, 37(2), 223-240.

Agbodeka, F. (1977). Achimota in the national setting: A unique educational experiment in West Africa. Accra, Ghana: Afram Publications.

Akyeampong, K. (2010). 50 years of educational progress and challenge in Ghana. Falmer, UK: Consortium for Research on Educational Access, Transitions and Equity (CREATE), Centre for International Education.

Alabi, G., \& Alabi, J. (2014). Understanding the factors that influence leadership effectiveness of Deans in Ghana. JHEA/RESA, 12(1), 111-132.

Amenumey, F., \& Yawson, R. (2013). Conceptualization and description of HRD in Ghana. In Celebrating 20 years of Leading HRD through Research. Proceedings of the 20th Annual AHRD International Research Conference in the Americas (pp. 1-11). Arlington, VA: Academy of Human Resource Development.

Bennis, W. (1996). The leader as storyteller. Harvard Business Review, 74(1), 154-161.

Bolden, R., \& Kirk, P. (2009). African leadership: Surfacing new understandings through leadership development. International Journal of Cross Cultural Management, 9(1), 69-86 http://doi.org/10.1177/1470595808101156.

Columbia University. (2012). Ghana. In The Columbia electronic Encyclopedia (6th ed.). New York: Columbia University Press. 
Dziczkowski, J. (2013). Mentoring and leadership development. The Educational Forum, 77(3), 351-360 http://doi.org/10.1080/00131725.2013.792896.

Edoho, F. M. (2001). Management in Africa: The quest for a philosophical framework. In F. M. Edoho (Ed.), Management challenges for Africa in the twentyfirst century: Theoretical and applied perspectives (p. 304). New York: Praeger Publishers.

Gibson, C. B. (1995). An investigation of gender differences in leadership across four countries. Journal of International Business Studies, 26(2), 255-279.

Harris, J., \& Barnes, B. K. (2006). Leadership storytelling. Industrial and Commercial Training, 38(7), 350-353.

Jones, A., Jones, C., \& Ndaruhutse, S. (2014). Higher education and developmental leadership: The case of Ghana. Canberra, ACT: Developmental Leadership Program (DLP).

Mackenzie, A. (2014). Storytelling is at the heart of leadership. Cranfield: Cranfield University, Bedfordshire, UK.

Mccormick, I., \& Burch, G. S. J. (2008). Personality-focused coaching for leadership development. Consulting Psychology Journal: Practice and Research, 60(3), 267-278.

Mintzberg, H. (2010). Developing leaders? Developing countries? Oxford Leadership Journal, 1(2), 1-10.

Nelson, T., Ingols, C., Christian-Murtie, J., \& Myers, P. (2013). Susan Murcott and pure home water: Building a sustainable mission-driven enterprise in Northern Ghana. Entrepreneurship Theory and Practice, 37(4), 961-979.

Nilsson, A. (2003). Ghanaian christianity between cultural tradition and modernity. Örebro Theological Seminary.

Nkomo, S. M. (2006). Images of African leadership and management in organisation studies: Tentions, contradictions and re-visions. Inaugural lecture. Pretoria, RSA.

O'Flaherty, C., \& Everson, J. (2005). Coaching in leadership development. In J. Kagan \& A. Böhmert (Eds.), Brain-based executive education (pp. 1-13). Johannesburg, RSA: Knowres Publishing.

Ray, D. I. (2003). Ghana: Traditional leadership and rural local governance. In D. I. Ray \& P. S. Reddy (Eds.), Grassroots governance?: Chiefs in Africa and the Afro-Caribbean (pp. 83-122). Calgary, AB: University of Calgary Press.

Ready, D. A. (2002). How storytelling builds next-generation leaders. MIT Sloan Management Review, 43(4), 63-69.

Salm, S. J., \& Falola, T. (2002). Culture and customs of Ghana. Westport, CT: Greenwood Publishing Group. 